\title{
Still having a conflict potential? German and Hungarian toponyms in the Czech and Slovak national corpora texts
}

\begin{abstract}
The paper focuses on German forms of place names in Czechia and Slovakia, and Hungarian forms of place names in Slovakia, especially on their revitalization and perception after 1989. This concerns their thematization, which is illustrated on the Czech National Corpus and the Slovak National Corpus materials, and on the 1990s discussions about their restoration. German place-name forms are not considered to be a crucial political topic these days; however, Hungarian forms still represent a conflict potential. German forms in Czechia are only thematized in poetry and fiction books, in order to evoke lasting time and the complicated modern Czech history. On the other hand, they are predominantly used in trade names as a marketing tool aimed at German (localization function) and Czech customers (allusive function). In Slovakia, Hungarian forms are not used in marketing and are not thematized in fiction as a positive value connected with the national history.
\end{abstract}

\section{Keywords}

German place names $\bullet$ Hungarian place names $\cdot$ marketing $\bullet$ Place names - political onomastics $\cdot$ revitalization

(C) University of Warsaw - Faculty of Geography and Regional Studies
Jaroslav David' Tereza Klemensová ${ }^{2}$

'Department of Czech Language, Faculty of Arts, University of Ostrava, Ostrava, Czech Republic e-mail: jaroslav.david@osu.cz

${ }^{2}$ Department of Czech Language, Faculty of Arts, University of Ostrava, Ostrava, Czech Republic e-mail: tereza.klemensova@osu.cz

Received: 5 November 2018 Accepted: 4 January 2019
Introduction

The present study - on the examples of historical German geographical names in the Czech Republic, and of historical German and Hungarian geographical names in the Slovak Republic - focuses on the issues of thematisation, memory, revitalisation and marketing use of toponymy of national minorities, treating all these from the viewpoint of the present day. We will focus on the post-1989 treatment and destinies of the German toponymy of Czech lands (used as a synonym for the Czech Republic); more particularly, the study investigates whether the German names have been thematised in newspaper articles, whether they have become standardised once again (by renaming or revitalisation), and whether they are used in marketing - and, if so, in what forms. The situation in the Czech Republic is compared to the state of the revitalisation of historical German toponymy in Slovakia; here, special attention is also paid to the usage of living Hungarian toponymy.

\section{German toponymy}

Multilingual forms of geographical names are a mark and result of a complicated historical development, which holds true especially for Central Europe. The most important localities in the present-day Czech and Slovak Republics (former Czechoslovakia, 1918-1993) bear - in addition to their Czech/Slovak name forms - historical, non-standard variants of German origin, which could be primary (Reichenberg $>$ Liberec, Metzenseifen > Medzev) or were created secondarily by means of the adaptation of the Slavic toponym (Brno > Brünn, Žilina $>$ Sillein); alternatively, there could be two independent forms (Krnov/Jägerndorf, Spišské Podhradie/Kirchdrauf). The system of Czech/Slovak-German double-naming had been functional until 1945, when, in relation to the new, post-war organisation of Europe, the German population was relocated, and the German toponymy revised and changed (via Bohemisation, Slovakisation or renaming) (Majtán 1998; Matúšová 2015). If one compares the data from the last pre-war census (1930), when the German population formed $30 \%$ of the people (the Czech Republic, hereinafter referred to as "Czechia")/5\% of the people (the Slovak Republic, hereinafter referred to as "Slovakia"), with the present-day situation (2011), when it forms as little as $0.2 \%$ (Czechia)/0.1\% (Slovakia), it may be concluded that to speak about practical (administrative, communicative) function, or even the necessity to use the German names of Czech settlements, makes no sense at all.

However, given the background of an intensive interest in the destinies of "disappeared neighbours" (Jews, Germans), which emerged in the previous two decades (fiction, film, theatre, exhibitions, conferences and academic papers, including onomastic research; cf. the newest studies by Boháčová 2014; Matúšová 2015; Lábus 2016), it seems that German toponymy is not a bookish or academic matter, but rather becomes a topic in the public space again, predominantly in Czechia.

\section{German toponymy in Czechia}

Material

The basis for choosing the researched set of names was the aforementioned last pre-war census (Statistický lexikon obci České republiky I 1934; || 1935). The criteria for selecting 50 locality names were determined in the following way: according to the 1930 
census, we selected independent settlements with populations of more than 5,000 each; next, these localities were ranked according to the proportion of the German minority settled in them. The set of the first 50 names, in which there were places such as Krásná Lípa/Schönlinde, Karlovy VarylKarlsbad, or Liberec/Reichenberg, was closed by Kynšperk nad Ohřil Königsberg an der Eger (97\% of the German population) and Český Krumlov/Krumau (74\%). Then, the occurrences of pre-war (German or Germanised) name variants were researched in the Czech National Corpus and the Business Register (see later). In case the locality was given a new name after 1945 (Falknov nad OhřllFalkenau an der Eger, nowadays Sokolov; Frývaldovl Freiwaldau, nowadays Jeseník), the two pre-war name variants (the Bohemised and the German ones) were searched for in the corpus.

Thematisation of German toponyms in opinion-journalism Articles - examples from the Czech National corpus

Covering the first topic, we have carried out four investigations into the Czech National Corpus (CNC) material, namely into the synchronic corpora of SYN2000, SYN2005, SYN2010 and SYN2015. ${ }^{1}$ These are representative and referential (closed) corpora of texts which cover the period of 1990-2014. Given the facts that the occurrences of the researched toponyms were not very numerous and that - opinion journalism excluded - it was irrelevant to follow their timescale, the analysis was not focused chronologically.

We were not surprised by the finding that in field (i.e. academic) literature, the researched German toponyms occurred quite a lot, namely as forms stated next to the Czech names in papers focused on history. On the other hand, we expected significant occurrences of German name variants in opinion journalism, given both their up-to-datedness and the topics of the Czech-German relations and the settlement of modern-history grievances, which were prominent after 1989. Nevertheless, our assumption was not confirmed here. Articles with political (or political and historical) overtones appeared rarely, in very small numbers ("Czech people do not always bear with calm faces the fact that Germans diligently refer to Czech cities with their historical German names: Eger (Cheb), Falkenau (Sokolov), Tachau (Tachov) or Karlsbad (Karlovy Vary) or the Nazi-infused expression 'Tschechei' (Czech land)").

The third group of the analysed texts is fiction. Here, the use of German names either refer back to the pre-war period - mostly, it concerned the memoir-like fiction taking place in the past (example.g. "He was the one who could speak Czech, and who, therefore, had a special order to make his way to the archives of the befriended Slovak State and, later, to the vicinity of his birthplace in the Protectorate, to the archives in Cheb, Liberec, then to Opava and, finally, to Frývaldov, which he knew so intimately.") - or the German (Germanised) names were, as to motives, revived in poems and lyrics.

Revitalisation of German toponymy in public spaces

Revitalisation, or a renewal or revival of a German local name, can take place in two forms - at the official (public) level, when a settlement restarts using its original German name or in the form of transonymisation of the original oikonym to other than settlement objects, namely the shift to the sphere of chrematonymy or anthroponymy (exceptionally only, in the form of pennames or nicknames - for example, nom-de-plume Marie Freiwaldau, or a Facebook nick Jitka von Reichenberg).

${ }^{1} \mathrm{~A}$ language corpus represents a set of authentic texts (written or spoken ones) in which it is easily possible to search for linguistic phenomena (namely words and collocations) and display them in their natural contexts; cf., for instance, British National Corpus, Russian National Corpus, Polish National Corpus.
First, we focused on the revival of German toponyms. On the basis of the Statistical Lexicon of Settlements of the Czech Republic (Statistický lexikon obcí České republiky 1994; 2007; 2013; Malý lexikon obcí České republiky 2014; 2015; 2016), we found out that in the 1989-2016 period, only four cases were put into practice. Except for the township Křžová (1949-1991, the Havličkův Brod district), which renewed its historical name of Krucemburk, it concerned small settlements, or local quarters only: Strážka > Varta (1991, the Písek district), Želenov > Frymburk (1992, the Klatovy district), Zlaté Hory > Kamberk (1993, the Benešov district). Besides these changes, which reflected themselves in the Czech toponymy, there are, however, attested attempts to change names and revive the pre-war (German) name forms, which were not put into practice (we followed the discussions in the periodicals included in the ANL database (2017) or we contacted the local authorities of the given settlements). Of all researched localities, the renaming proposal only appeared in the city of Jeseník, Freiwaldau in German, Frývaldov in Czech and the post-war name of which was derived from the Jeseníky mountain range name. However, the Jesenik-Frývaldov change was rejected both by the local authorities and the local historians. The proposal of a former Jeseník citizen, who considered the adapted name Frývaldov linguistically Czech (comparing it to Trutnov, Trautenau in German, which remained Trutnov and was not renamed Krkonoš, according to the Krkonoše mountain range) and, thereafter, called the post-1945 change "a misstep", was rejected by the local authorities on the grounds of three reasons. Besides the costs needed for the operationalisation of the project, the authorities mentioned the deep-rootedness of the Jeseník name, which serves for promoting the city (which is also linked to the funds already invested into the sphere of tourism), and articulated their fears about the negative reactions of the local people following the renaming, pointing out the emotional background of the whole project. In the same way, the decision of the Jeseník State District Archives highlighted the deeprootedness of the Jeseník name and deemed its change counterproductive.

The second topic, which was focused on within revitalisation, was transonymisation of the German name variants from the sphere of settlement names (toponymy, oikonymy) to the sphere of chrematonymy (names of companies, institutions, etc.). In this case, we also researched the set of selected 50 toponyms, and on the material of the company names written down in the Business Register (Obchodní rejstřik 2017), we were trying to find out whether the given forms are used, and whether they are characteristic of the region with the historically attested German population. In the Register, we noted 80 company names which made use of the German (pre-war) toponym, e.g. Taxi Aussig s. r. o., BOHEMIA HEALING MARIENBAD WATERS a. s., or Klub hledačů a prátel historie Maffersdorf. A couple of Pragueseated firms left aside, all of them were headquartered in the borderland regions. The highest occurrences were made by names Marienbad (37 times, Mariánské Lázně), then Eger (14 times, Cheb), Karlsbad (10 times, Karlovy Vary), Reichenberg (4 times, Liberec), Aussig (3 times, Ústí nad Labem), Asch (2 times, Aš), Falknov (2 times, Sokolov) ${ }^{2}$. The enumeration makes it clear that the German names are made use of in company names by firms headquartered in the cities near the German borders. Other names only appeared with the frequency of one. Besides the Business Register records, the German name forms are also employed in other chrematonyms (CD Freiwaldau by the Priessnitz music band, the Café Reichenberg theatre

${ }^{2}$ However, on a large scale, German names are not an important naming motive: for the sake of illustration, the data of the city of Mariánské Lázně are presented here. As of 30 May 2018 , there were 59,620 companies in the city, out of which only 26 made use of the Marienbad name (i.e. $0.04 \%$ ). To compare, the Mariánské Lázně toponym (or the mariánskolázeňský adjective) appeared in 278 company names (i.e. $0.47 \%$ ). 
performance, the music bands such as Brüx Colony, Motörhead Reichenberg, Šanov), in the names of restaurants and boarding facilities (the Falknow CAFE café, the Carlsbad Plaza hotel, the Eger boarding house) or in event names (the Marienbad Film Festival film festival, the Frývaldovský DoCENT cycling race).

\section{German toponymy in Slovakia}

In the Introduction, we stated that, whereas the topic of "German neighbours" is very prominent in the Czech public discourse, arts, and social sciences, in Slovakia, the situation is different. A possible explanation may be the ongoing taboo connected to the German minority and their post-war destiny, but also the fact that Germans were much less numerous in the local pre-war population (5\%) compared to the situation in the Czechlands (30\%). This was the reason why we have proceeded to amend the criterion for the choice of researched localities. We have only focused on the cities, the populations of which were, in 1930, at least 3,000 each and, at the same time, which had at least a 5 per cent share of the German minority. In the choice, we detected 15 localities, e.g., Bratislava/Pressburg, Pezinok/ Bösing, or Lučenec/Lizenc, including Gelnica/Göllnitz with the highest $(47 \%)$ and Trenčin/Trentschin $(5 \%)$ with the lowest proportion of Germans. Unlike the Czechia research, we added to the set of Slovak cities the locality of Medzev/Metzenseifen, which was the only one to fit into the set-up parameters according to the latest census $(2011$; i.e. the minimal population of 3,000 , and a 5 per cent share of the German minority). These 16 German name forms of Slovak cities were first researched in the synchronic material of the Slovak National Corpus, the prim8.0 version (SNK 2018), namely in opinion journalism, academic writing and fiction (for details).

Most - 9 - German names occurred in opinion journalism (Pressburg/Bratislava, Göllnitz/Gelnica, Leibitz/L'ubica, Bösing/ Pezinok, Kirchdrauf/Spišské Pohradie, Sillein/Žilina, Rosenberg/ Ružomberok, Modern/Modra, Trentschin/Trenčín; the source documents are mostly local periodicals), only 4 were found in academic writing (Pressburg/Bratislava, Bösing/Pezinok, Leutschau/Levoča, Trentschin/Trenčín), and only 2 in fiction (Pressburg/Bratislava, Leibitz/L'ubica). A closer look at the distribution and context of the occurrences demonstrates a situation comparable to the one in the Czechlands. In the Slovak texts, the German forms occur as historical equivalents to geographical names, with the only exception of Pressburg/ Bratislava, where the type of texts does not play part. The German name for the capital is not thematised on the national basis, but with historical and nostalgic vibes. This is well evidenced in the following example: "In Bratislava, the contemporary capital of the young Slovak Republic, the old city names of Pressburg and Pozsony are still living - there are guiding marks of a remarkable history. Pressburg used to be a geographical term - a provincial town between Vienna and Budapest. Nowadays, Pressburg is a sentimental notion, a soul landscape, which lives on, the same as the fabulous Atlantis, merely in storytelling, in the tales the old generation can present in their typical, fitting, kindly ironical Prešpork speech."

The same as in the Czech material, in Slovak opinion journalism, German toponyms are not prominently thematised in relation to the destinies of the German ethnicity. There is an exception of the commentary by Peter Schutz "Essence of Nationalism", published in the nationwide daily SME, discussing the dispute about presenting Hungarian names in Slovak textbooks: "If Slovakia, Heaven forbid, were annexed by Germany in ten years' time, would the name of Trenčín - given his way thinking - be also outdated, and would it be only possible to write Trentschin in Slovak textbooks, too? Why does the Slovak government mention the Hungarian village of Mlynky, and not, for example, Pilisszentkereszte? The inability to understand that someone else calls things in a different way is the essence of nationalism." However, the German name form of Trentschin is not a topic here, but only a hyperbolised example used in the dispute about the Hungarian name forms.

The same can be deduced from the investigations in the (Slovak) Business Register, where - with the exception of two forms, Dobschau and Rosenberg, with one occurrence each there is only Pressburg occurring more than once, namely 52 times, for example in Pressburg Media, s. r. o., Pressburg Style, s. r. o., or PRESS \& BURG Finance, s. r. o. ${ }^{3}$

\section{Hungarian toponymy in Slovakia}

In the case of the second investigation, we have focused on the Hungarian name variants of Slovak cities. Using the criterion of the minimal population of 3,000 and a 5-per cent share of the Hungarian national minority, we have put together a set of 21 names, both censuses being represented (1930, 2011); the border localities for the pre-war period are Komárno/Komárom (60\%) and Spišská Nová Ves/lgló (5\%), for the present day, cities of Gabčíkovo/Bös (88\%) and Levice/Léva (9\%).

Given the fact that Hungarians form $8.5 \%$ of the presentday Slovak population, it is understandable that Hungarian forms occur namely in opinion journalism, predominantly in the articles focusing on usage of multilingual inscriptions, e.g. "This would mean that on entering Hurbanovo, we would not only be welcomed by the Hurbanovo inscription table, but also with the Ógyalla one. The reactions of the citizens of the involved cities to Csáky's initiative were searched for among the local authorities." Here, however, it is essential to distinguish between two types of Hungarian name forms - those that are currently standardised (the law no. 184/1999 amendment of 2011 determines the 20-per cent representation of the minority in a settlement for an option to use a second language, including inscriptions and toponyms), and those that had only been in operation until the 1948 "standardising" adjustment on the basis of which several tens of settlements were renamed (David 2011). In our material, this second type is represented by Slovakised forms of Hungarian names Beš (Bös - Gabčíkovo), Guta (Gúta - Kolárovo), Parkan (Párkány - Štúrovo), and Stará Ďala (Ógyalla - Hurbanovo); to these, we also add Čalovo (1948-1990, nowadays Nagymegyer - Vel'ký Meder).

The present standardised forms appeared in academic texts, but predominantly in opinion journalism (besides these, there is one occurrence in fiction, too). In opinion journalism, the situation is different, compared to the one of the aforementioned occurrence of German variants. Given the numerous Hungarian minority and historical animosities (until 1918, Slovakia had been part of Hungary and had been exposed to strong Hungarianisation), the Hungarian forms of Slovak cities - including Pozsony for Bratislava - are the core topics for opinion texts, which reflect individual disputes, for instance the 2008 discussion about presenting Hungarian toponym forms in textbooks, etc. Compare, too, the following excerpt: "Despite the fact that there are 70 percent of the Hungarian population living in Štúrovo, the historical name of Parkány can be written next to the official name place only with a highlighter. This grievance, which was established already by the Communist regime, would deserve to be deleted," thinks Chmel.

On the other hand, the non-standardised names (Beš, Guta, etc.) had no representation in opinion journalism at all, their occurrences appearing in academic writing and fiction only.

${ }^{3}$ The same as in Czechia, the German names are not frequent naming motives in Slovakia either. As of 29 May 2018, the Pressburg toponym was employed in Bratislava (the Bratislava I court district) in $0.1 \%$ of business names (i.e. 58 times), the Bratislava toponym (or the bratislavsky adjective) in $1.73 \%$ of them (i.e. 1,033 times). 
However, their usage differs from the situation of the German toponyms (see above) - in the corpus, there are pieces of historical fiction, where the forms Beš, Guta, Parkan and Stará Dula fulfil the function of a "local colour" which flavours the authenticity of the treated historical subject; cf., for instance, "Palacký, not knowing anything, continues in his calm studies of grammar and rhetoric, philosophy and theology, at Bratislava's grammar school, writing poems, too; however, it was not until he was a tutor and teacher at the house of the noble Lady of Č́za near Stará Ďala that he became a mature man and scholar. He studied, entertained himself there and played tarots. I am the history, says the haughty navel."; the Čalovo form appears in the books published before 1990, when the name was changed.

To conclude, a look into the Business Register shows that using Hungarian name forms in the names of companies does not manifest any peculiar trend; there are small numbers of names (e.g. Komárom Trans s. r. o., Kassa Real, s. r. o., GútaNet s. r. o). Unlike the historical German form of Pressburg, the living Hungarian form of Pozsony makes no appearance at all.

\section{Conclusions}

Our research has primarily focused on using historical German name forms of Czech localities; their historicity is caused both by the lack of present-day standardisation and by the 60 -year absence of a notable German minority. The analysis of opinion-journalism texts brought about a finding that German name variants do not represent a conflict-provoking topic of the Czech political debate, even though the German question itself is an issue with high controversy. On the other hand, German forms make their appearances in fiction, where they serve as a device evoking the pre-war past and symbolise the irreversible flow of time. However, German variants of the contemporary Czech toponyms also have a tendency to lean towards transonymisation, penetrating into the public space, especially to the domain of chrematonymy. This process is put into practice in two ways. First, these names appear in the company names in the German borderland areas, notably in Northern Bohemia, where they take part in marketing strategies focused on the German-speaking environment; second, they appear in the names of tourist objects in the areas with no direct contact with the German areas, where they focus mostly on Czech tourists, bearing rather an illusory function.

Similar results were brought about by the comparative insight into the situation in Slovakia, where there is no significant German community either. Nowadays, German name forms of Slovak localities are only used as evidence with historical validity in opinion journalism and academic texts. The absence of German toponymy in Slovak fiction and, on the other hand, its rich thematisation in Czech fiction cannot be explained solely by the differences in the number of the German minority in both countries, but also by the differences in its perception. For Czechs, Germans were "age-old enemies" who the accounts were settled with in 1945; and it is not earlier than nowadays that the dramatic (predominantly 20th century) development of relations is being rediscovered as a topic, mostly demystified and relativised. Besides a less open relation of the Slovak society to its own modern history, a role is played by the fact that from the Slovak perspective, the core one is the relationship to Hungarians, not to Germans. The only one German name Pressburg (Bratislava) - is significantly thematised as a synonym for good old times, and is made use of in chrematonymy, too.

The second survey has focused on using selected Hungarian name forms of Slovak settlements; it needs to be noted that unlike German toponyms, these are linked to a considerably represented national minority. Hungarian forms are thematised the most in public journalism, but they, with the exception of older, nowadays non-standardised variants, make no appearances in fiction, or in chrematonymy. What is manifested here is the biggest difference between the Czech and Slovak states of affairs, which can be, on the grounds of our analysis, generalised. The Czech situation of a nationally homogeneous society differs from the one of Slovakia, where the disputes concerning Hungarian settlement names have presented, up to nowadays, a political theme with a high conflict potential, but they also reflect themselves in the post-1989 changes of standardised toponymy, for example Švermovo (1948-1990) > Telgárt, Palkovičovo (1948-1990) > Sáp, Šafárikovo (1948-1990) > Tornal'a; or else, they are objects of unsuccessful attempts at renaming, e.g. Štúrovo (> Parkan, 1992), Tešedíkovo (> Pered, 2012). It, therefore, goes without saying that it is the presence of a national minority and a living contact with it that determines in which spheres of communication and with what intention the minority forms will be used.

\section{Acknowledgement}

This research was supported by the University of Ostrava's internal grant (SGS) project no. 02/FF/2018-2019 Vytváření reality prostřednictvím jazyka - kvalitativní analýza novočeských textů [Reality Creation through Language - A Qualitative Analysis of Modern Czech Texts].

\section{References}

ANL 2017, Výběr článků $v$ českých novinách, časopisech a sbornicich [Articles from Czech Newspapers and Periodicals]. Available from: <https://aleph.nkp.cz/ $F /$ ?func=file\&file_name=find-b\&local_base=anl>. December 2017].

Boháčová, M 2014, 'Kontinuita anoikonymie v jihomoravském pohraniči' [Continuity of filed names in South Moravian borderlands], Acta onomastica, vol. 55, pp. 24-31.

ČNK 2017, Český národní korpus [Czech National Corpus]. Available from: <https://www.korpus.cz>. [15 April 2017].

David, J 2011, Smrdov, Brežněves a Rychlonožkova ulice. Kapitoly z moderní české toponymie [Smrdov, Brežněves and Rychlonožkova street. Chapters from Modern Czech Toponymy], Academia, Praha.

Lábus, V 2016, 'Německé stopy v současné toponymii Jizerských hor' [German traces in current toponymy of Jizera Mountain] in Toponyma - kulturní dědictví a pamět' míst, ed J David, Ostravská Univerzita, Ostrava, pp. 116-133.
Majtán, M 1998, Názvy obcí Slovenskej republiky. Vývin $v$ rokoch 1773-1997 [Names of municipalities of the Slovak Republic. Developments in the years 1773-1997]. Veda, Bratislava.

Matúšová, J 2015, Německá vlastní jména v češtině [German proper names in the Czech language], Nakladatelství Lidové noviny, Praha.

Obchodní rejstřík [Business Register] 2017, Veřejný rejstřík a Sbírka listin. Available from: <https://or.justice.cz/ias/ui/ rejstrik>. [15 April 2017].

Obchodný register [Business Register] 2018. Available from: <http://www.orsr.sk/search_subjekt.asp>. [29 March 2018].

SNK 2018, Slovenský národný korpus [Slovak National Corpus]. Available from: <http://korpus.juls.savba.sk>. [29 March 2018].

Malý lexikon obci České republiky [A Small Lexicon of the Settlements of the Czech Republic] 2014; 2015; 2016. Available from: <https://www.czso.cz/csu/czso/maly-lexikonobci-ceske-republiky-2014-n-gdc2kaznu1>. [15 April 2018]. 
MISCELLANEA GEOGRAPHICA - REGIONAL STUDIES ON DEVELOPMENT

Vol. 23 • No. 3 • 2019 • pp. 158-162 • ISSN: 2084-6118 • DOI: 10.2478/mgrsd-2019-0005

Sčitanie obyvatelov, domov a bytov [The Census] 2011. Available from: <https://slovak.statistics.sk>. [10 March 2018].

Statistický lexikon obci České republiky 1992 [The Statistical Lexicon of Settlements in the Czechoslovak Republic 1992] 1994, SEVT, Praha.

Statistický lexikon obcí České republiky 2007, 2013 [The Statistical Lexicon of Settlements in the Czechoslovak Republic 2007, 2013]. Available from: <https://www.czso.cz/ csu/czso/home>. [15 April 2018].

Statistický lexikon obcí v Republice československé I-II 1934; 1935 [The Statistical Lexicon of Settlements in the Czechoslovak Republic I-II], Orbis, Praha.

Štatistický lexikon obcí v krajine slovenskej 1936 [The Statistical Lexicon of Settlements in the Slovakia], Orbis, Praha. 